\title{
METODE BELAJAR DEMONSTRASI DAN EKSPERIMEN DALAM MATAPELAJARAN SAINS SEKOLAH DASAR (SD)
}

\author{
Muhammad Nizaar \\ Dosen Program Studi Pendidikan Geografi, Universitas Muhammadiyah Mataram \\ Email : nizar@fkip.ummat.ac.id
}

\begin{abstract}
ABSTRAK
Merujuk dari tiga tipe belajar, yakni tipe belajar visual (melihat), auditori (mendengar), dan kinestetik (gerakan atau sentuhan) maka diharapkan pembelajaran dapat mengaktifkan ketiga tipe tersebut pada diri siswa. Tujuan pengajaran Sains di Sekolah Dasar antara lain adalah agar siswa dapat memahami konsep-konsep Sains yang terkait dengan kehidupan sehari-hari, mampu menerapkan konsep tersebut dalam kehidupan, dan mampu memecahkan masalah yang timbul dalam kehidupan, mempunyai minat untuk mengenal dan mempelajari bendabenda serta kejadian di lingkungan sekitar. Oleh karena itu hendaknya pembelajaran diarahkan pada pengenalan secara langsung benda dan fenomen yang dipelajari. Awal diperolehnya ilmu pengetahuan merupakan hasil percobaan (eksperiment) yang dilakukan oleh para peneliti secara terus menerus melalui kegiatan coba-coba (trial and error). Dengan demikian, tidak salah kiranya dalam proses konstruksi pengetahuan sains siswa digunakan metode eksperimen. Sedangkan bentuk inprovisasi dari metode eksperimen dalam pembelajaran yang hanya dilakukan oleh seseorang dan diamati oleh orang lain disebut metode pembelajaran demonstrasi. Kegiatan eksperimen bertujuan untuk mengenal konsep dan dapat pula digunakan untuk membuktikan konsep. Eksperimen tepat dilaksanakan pada siswa SD karena anak umur 8 atau 9 tahun senang terhadap hal-hal yang konkret serta didukung oleh peningkatan rasa ingin tahu terhadap variabel-variabel tertentu. Kegiatan eksperimen tepat digunakan apabila memiliki media yang cukup, namun apabila tidak cukup dapat dilakukan melalui demonstrasi. Pola demonstrasi yang dapat dilakukan yaitu; teacher demonstration, teacher-student demonstrastion, student group demonstration, individual demonstration, dan guest demonstration. Muara keberhasilan belajar sains yaitu meningkatnya minat belajar melalui; kegiatan yang melibatkan siswa, adanya sentuhan psikologis dan pengertian, suasana adil dan demokratis.
\end{abstract}

Kata Kunci : Metode Belajar Demonstrasi dan Eksperimen

\section{A. Pendahuluan}

Sekolah memiliki peran yang penting dalam mengembangkan potensi anak menjadi manusia yang bermutu. Dalam rangka menciptakan sumber daya manusia yang bermutu diperlukan layanan pendidikan yang berorientasi pada kebutuhan siswa. Sesuai dengan amanat Undang-Undang Nomor 20 Tahun 2003 tentang sistem pendidikan nasional pasal 5 ayat 1 disebutkan bahwa setiap warga negara mempunyai hak yang sama untuk memperoleh pendidikan yang bermutu. Namun dalam implementasinya masih belum adanya konsistensi terhadap upaya memberikan layanan bagi setiap warga negara secara merata terutama dalam hal proses belajarmengajar.

Sekolah Dasar sebagai satuan pendidikan yang memiliki peran dalam proses membangun karakter anak perlu terus dibenahi dan ditingkatkan mutunya. Permasalahan mendasar untuk mencapai tujuan tersebut adalah kurangnya kompetensi guru dalam mengajarkan sains pada siswa Sekolah Dasar.

Merujuk dari tiga tipe belajar, yakni tipe belajar visual (melihat), auditori (mendengar), dan kinestetik (gerakan atau sentuhan) (Iwan Sugiarto, 2004: 18) maka diharapkan pembelajaran dapat mengaktifkan ketiga tipe tersebut pada diri siswa.

Tujuan pengajaran Sains di Sekolah Dasar antara lain adalah agar siswa dapat memahami konsep-konsep Sains yang terkait dengan kehidupan sehari-hari, mampu menerapkan konsep tersebut dalam kehidupan, dan mampu memecahkan masalah yang timbul dalam kehidupan, mempunyai minat untuk mengenal dan mempelajari benda-benda serta kejadian di lingkungan sekitar. Oleh karena itu hendaknya pembelajaran diarahkan pada pengenalan secara langsung benda dan fenomen yang dipelajari. Awal diperolehnya ilmu pengetahuan merupakan hasil percobaan (eksperiment) yang dilakukan oleh para peneliti secara terus 
menerus melalui kegiatan coba-coba (trial and error). Dengan demikian, tidak salah kiranya dalam proses konstruksi pengetahuan sains siswa digunakan metode eksperimen. Sedangkan bentuk inprovisasi dari metode eksperimen dalam pembelajaran yang hanya dilakukan oleh seseorang dan diamati oleh orang lain disebut metode pembelajaran demonstrasi.

\section{B. Hakikat Pelajaran Sains di SD}

Menurut James Conant dalam Sumaji et al. (2007: 31), sains didevinisikan sebagai suatu deretan konsep serta skema konseptual yang berhubungan satu sama lain, dan yang tumbuh sebagai hasil eksperimentasi dan observasi, serta berguna untuk diobservasi dan dieksperimenkan lagi.

Makna tersebut di atas mencakup makna paradigmatis dan praktis. Makna paradigmatisnya mengandung bahwa sains merupakan suatu proses seni (art) membangun pola pikir ilmiah. Pola pikir tersebut dapat berupa konsep-konsep, prinsip-prinsip (principles), seni beretorika (rhetoric art), dan seni berlogika (logic art). Sedangkan makna praktisnya yaitu suatu kegiatan yang membangun sikap ilmiah dalam bentuk eksperimen dan observasi untuk mengetahui suatu permasalahan serta hal tersebut masih berpeluang untuk dibuktikan lagi oleh orang lain.

Dengan demikian, proses pembelajaran sains perlu dikembalikan pada hakikat dasarnya yaitu membangun pola pikir yang ilmiah melalui eksperimen dan observasi (demonstrasi) yang melibatkan siswa secara langsung.

Berdasarkan hasil penelitian dari Dr. Jean Piaget bersama rekan-rekannya dalam Carin dan Sund (1981: 15) di University of Geneva, Switzerland selama lebih kurang 60 tahun mendapatkan kesimpulan bahwa terdapat beberapa tingkat perkembangan mental dan kognitif anak, yaitu:

1. Sensorimotor stage (0-2 years)

2. Preoperational stage (2-7 years)

3. Concrete-operational stage (7-11 years)

4. Formal-operational stage (11-14+ years)

$\mathrm{Di}$ Indonesia umur anak-anak yang dimasukan ke Sekolah Dasar berkisar 8-11 tahun (Depdiknas, 2004). Berarti umur Sekolah Dasar masuk dalam kategori ke-3 dari tahap perkembangan yang dikemukankan oleh Piaget, yakni tahap berpikir konkrit.

Lebih lanjut menurut Piaget dalam Carin dan Sund (1981: 29) menyatakan bahwa pada umur 7-11 tahun bentuk-bentuk karakter berpikirnya yakni:

Performs operations: combining, separating, ordering, seriating, multiplying or repeating, deviding, substituting, and "reversible" thinking, can do correspondence by end of period, analizes, is aware of variabels, classifies, and measures.

Conserves: volume, weight, and area.

Konsep yang diungkapkan oleh Piaget tersebut mencakup dua kemampuan yang dimiliki oleh anak usia 7-11 tahun yakni membuat sistem kerja, mencakup; memadukan, memisahkan, mengurutkan, merangkai, melakukan pengulangan, membagi, dan berteka-teki, dapat melakukan penyocokan pada akhir kegiatan, menganalisa, mengetahui variavel-variabel, mengklasifikasikan, serta dapat mengukur. Dan yang kedua dapat mengukur dalam hal volum, berat, serta ukuran wilayah.

Dengan demikian pembelajaran sains di Sekolah Dasar menuntut adanya kemampuan guru dalam mengarahkan anak pada kemampuan berpikir konkrit. Kemampuan berpikir konkrit merupakan kemampuan melihat alam sekitar tempat ia berada sebagai bahan dan contoh langsung mengenai materi yang dipelajari.

\section{Kegiatan Eksperimen dan Demonstrasi Sebagai Metode Pembelajaran}

Faktor yang sangat berpengaruh bagi keberhasilan siswa dalam belajar ialah tepatnya metode yang digunakan guru. Jika guru tidak dapat menggunakan metode yang tepat dalam mengajar, siswa akan kesulitan menerima dan memahami materi pelajaran dengan baik.

Menurut Sutikno (2004: 106) pengertian dari metode adalah cara yang digunakan guru dalam mengadakan hubungan dengan siswa pada saat berlangsungnya proses belajar mengajar. Sedangkan menurut Yamin (2005: 64) istilah metode didefinisikan sebagai cara melakukan atau menyajikan, menguraikan, memberi contoh, dan memberi latihan isi pelajaran pada siswa untuk mencapai tujuan tertentu.

Metode belajar eksperimen dan demonstrasi. sering digunakan dalam pembelajaran sains karena kedua metode tersebut dapat mengarahkan siswa pada cara belajar dan melihat secara langsung objek yang 
dibicarakan. Ada kecenderung kedua metode tersebut dibahas secara bersamaan, namun pada kedua metode tersebut terdapat perbedaan-perbedaan yang mendasar.

\section{1) Metode belajar eksperimen}

Metode eksperimen adalah "cara penyajian pelajaran dengan menggunakan percobaan" (Nuryani, dkk, 2003: 129). Kegiatan eksperimen bukan merupakan kegiatan yang asing dalam bidang keilmuan sains. Berbagai penemuan dibidang ilmu pengetahuan alam bermula dari kegiatan mencoba dan mencoba secara terus menerus (trial and error). Melalui kegiatan tersebut maka suatu konstruksi teori dan hukum dapat dirumuskan oleh ahlinya. Pada proses pembelajaran sains pun diharapkan anak mampu memiliki kemampuan untuk mengkonstruksi pengetahuannya melalui pola pikir penyelidikan (inquiry). Penyelidikan di Sekolah Dasar tentunya berbeda dengan penyelidikan pada jenjang SMP dan SMA. Penyelidikan di Sekolah Dasar merupakan penyelidikan yang sederhana sesuai dengan perkembangan kemampuan berpikir siswa.

Dengan melakukan eksperimen, siswa akan menjadi lebih yakin atas suatu hal daripada hanya menerima dari guru dan buku, dapat memperkaya pengalaman, mengembangkan sikap ilmiah, dan hasil belajar bertahan lebih lama dalam ingatan. Namun kendala utama dalam menerapkan metode eksperimen adalah minimnya media yang dimiliki sekolah. Peralatan harus memadai sebab kegiatan eksperimen bukan seperti kegiatan demonstrasi. Melalui metode eksperimen siswa akan bekarja secara individu dan dapat juga dalam kelompok.

Pada matapelajaran sains SD tepat diterapkan kegiatan eksperimen sesuai dengan pendapat Kuslan dan Stone (1969: 51), "children of nine or eight or younger can isolate some variabels. These children if they are anxious to find the effect of a variabel, can try verify by observing or experimenting". Dari pendapat Kuslan dan Stone tersebut didapatkan bahwa siswa yang berumur 9 atau 8 tahun, bahkan dibawah dari 8 tahun, sudah dapat membedakan variabel-variabel. Anak-anak tersebut memiliki rasa keingintahuan yang tinggi untuk mengetahui variabel tersebut, telah mampu melakukan percobaan untuk membuktikannya melalui pengamatan dan eksperimentasi (percobaan).

Metode eksperimen dapat dilakukan dalam dua bentuk, yakni:

a) Sebelum siswa mengenal teori, dan

b) Setelah siswa mengenal teori (Anna Poedjiadi, 2005: 90)

Kegiatan eksperimen sebelum diperkenalkan suatu teori dapat merupakan suatu penemuan (inquiry) kalau pelajaran dirancang sedemikian rupa sehingga anak benar-benar merasa menemukan sendiri suatu konsep. Sedangkan kegiatan eksperimen setelah memperoleh suatu teori atau konsep adalah berfungsi sebagai verifikasi, karena bersifat menguji teori yang telah dibahas sebelumnya.

Untuk melaksanakan kegiatan eksperimen yang baik maka guru harus menyadari dengan baik tujuan dari eksperimen, hubungannya dengan materi, konsep yang telah dimiliki siswa, dan nilainilai yang terkandung dalam kegiatan eksperimen (Kuslan dan Stone, 1969: 249).

Melalui metode eksperimen diharapkan siswa dapat belajar lebih aktif mengamati sendiri objek yang sedang dipelajari. Oleh karena metode ini berpusat pada pengamatan terhdap proses dan hasil eksperimen maka diperlukan pedoman dan tata cara pengamatan atau percobaan yang dapat dilakukan oleh sendiri oleh siswa. Saran dari Soetomo (1993: 167) bahwa kegiatan eksperimen harus dilengkapi dengan lembar kerja siswa. Siswa Sekolah Dasar belum mampu untuk melakukan dan bertindak sendiri dalam proses percobaan, peran guru dalam mengarahkan individu dan kelompok yang bereksperimen sangat diperlukan. Guna mengarahkan kegiatan eksperimen maka siswa harus dilengkapi dengan lembar kerja yang biasanya memuat; tema percobaan, alat-dan bahan yang diunakan, prosedur kerja, hal-hal yang harus diobservasi, hal-hal yang perlu dicatat, serta kolom untuk membuat kesimpulan-kesimpulan.

\section{2) Metode belajar demonstrasi}

Metode demonstrasi dilakukan apabila di sekolah peralatan yang dimiliki kurang memadai untuk digunakan oleh siswa secara individu ataupun kelompok. Menurut Trowbridge \& Bybee (1990: 232) demonstrasi merupakan "process of 
showing something to another person or group". Lebih lanjut dijelaskan oleh Trowbridge \& Bybee bahwa dalam kegiatan eksperimen harus ada "feedback" dari siswa. Feedback merupakan tanggapan balik siswa terhadap demonstrasi yang sedang atau sudah dilaksanakan. Hal ini dimaksudkan agar guru mengetahui apakah siswa mengetahui dan memahami maksud dari rentetan kegiatan demonstrasi.

Dalam proses belajar mengajar sains, yang dimaksud dengan proses "menunjukan sesuatu" adalah suatu kegiatan memperlihatkan suatu fenomena atau kejadian yang diperagakan langsung oleh guru atau orang yang dianggap ahli. Proses demonstrastrasi seperti yang diungkapkan oleh Trowbridge dan Bybee di atas mengharapkan adanya kegiatan yang terarah dan terpimpin. Kegiatan diharapkan memiliki tujuan yang jelas. Kegiatan yang diperagakan sesuai dengan tujuan dari pembelajaran sains. Untuk mengetahui siswa mampu menangkap maksud dari percobaan maka guru diharapkan tetap melakukan interaksi dalam bentuk pertanyaan atau meminta tanggapan siswa terhadap demonstrasi yang dilakukan.

Demonstrasi tidak hanya dilakukan oleh guru pengajar, namun dapat dilakukan pula oleh subyek lain. Beberapa pola demontrasi yakni; 1) teacher demonstration, 2) teacherstudent demonstration, 3) student group demonstration, 4) individual student demonstration, dan 4) guest demonstration (Trowbridge \& Bybee, 1990: 235).

Demonstrasi oleh guru (teacher demonstration) merupakan kegiatan demonstrasi yang dilakukan oleh guru. Guru harus memiliki kemampuan yang memadai (sophisticated) agar terlihat menarik oleh siswa.

Demonstrasi guru-siswa (teacherstudent) merupakan demonstrasi yang dilakukan oleh dua orang atau beberapa orang siswa untuk membantu guru melakukan demonstrasi. Demonstrasi tersebut akan menarik perhatian siswa karena adanya salah satu teman mereka yang membantu guru.

Kelompok siswa demonstrasi (student group demosntration) merupakan kegiatan demonstrasi yang dilakukan oleh kelompok siswa tertentu. Kelompok siswa yang akan berdemonstrasi merupakan kelompok siswa yang terpilih karena dianggap mampu untuk melakukan demonstrasi.

Seorang siswa berdemonstrasi (individual student demonstration) merupakan kegiatan demonstrasi yang dilakukan oleh seorang siswa saja. Siswa tersebut merupakan siswa yang dianggap mampu memperlihatkan kemampuannya pada suatu bidang tertentu.

Demonstrasi oleh orang lain (guest demonstration), merupakan demonstrasi yang dilakukan oleh orang yang bukan dari guru pembimbing atau siswa. Orang tersebut dapat diundang secara khusus untuk memperagakan keahliannya. Cara terakhir ini akan sangat membantu guru dalam menarik perhatian siswa karena adanya suatu model (model) baru.

Beberapa pola demosntrasi di atas menandakan bahwa kegiatan demonstrasi bukan merupakan kegiatan yang monoton oleh guru saja. Kegiatan demonstrasi dapat bersumber dari siswa dalam kelas, siswa lain, guru, pakar atau ahli yang dapat memperlihatkan kepiawaiannya. Demonstrasi bukan semata-mata untuk kegiatan menghibur dan menarik perhatian siswa, namun kegiatan eksperimen diharapkan membantu guru agar siswa mudah dalam mencapai tujuan pembelajaran

\section{Bangkitnya minat siswa sebagai tolak ukur keberhasilan belajar sains}

Minat merupakan pembawaan dari pengalaman yang mendorong seseorang untuk memperhatikan suatu objek, kegiatan, atau suatu tujuan tertentu. Sedangkan menurut Surya (2004: 74) minat merupakan suatu perhatian yang diberikan pada suatu rangsangan, sehingga timbul penilaian suka dan tidak suka.

Untuk dapat membuat anak berminat, menurut G. J. Mouly (1968: 339) intinya adalah memberikan kepuasan (satisfaction) kepada siswa. Dari rasa puas akan memberikan minat yang tinggi.

Dari beberapa pandangan ahli di atas memberikan gambaran beberapa ciri dari siswa yang memiliki minat tinggi dalam proses pembelajaran, yaitu:

1) Memiliki motivasi yang tinggi untuk belajar

2) Memiliki rasa puas terhadap pelayanan selama proses belajar mengajar berlangsung 
3) Memiliki perhatian yang tinggi terhadap materi yang diajarkan guru

4) Terlibat aktif dalam proses pembelajaran. Keaktifan tersebut dapat dalam bentuk keinginan bertanya dan keinginan mengajukan pendapat

Beberapa komponen di atas dapat menjadi ciri dari keberminatan siswa pada proses pembelajaran. Untuk menunjang minat belajar siswa, maka proses pembelajaran harus berjalan dengan efektif. Menurut Surya (2004: 79) proses pembelajaran yang efektif memiliki ciri-ciri sebagai berikut: (1) semua kegiatan pembelajaran didominasi oleh siswa, (2) interaksi antara guru dan siswa hendaknya didasarkan pada sentuhan-setuhan psikologis, yaitu adanya saling pengertian antara guru dan siswa. (3) suasana yang demokratis akan memberikan minat siswa untuk berprestasi dan percaya diri, (4) guru melakukan variasi metode mengajar agar siswa tidak bosan, (5) lingkungan sekitar sekolah yang kondusif dan aman, dan (6) sarana belajar yang menunjang kegiatan belajar siswa.

\section{E. Kesimpulan}

Adapun kesimpulan yang diperoleh dari kajian ini yaitu:

a. Kegiatan eksperimen bertujuan untuk mengenal konsep dan dapat pula digunakan untuk membuktikan konsep

b. Eksperimen tepat dilaksanakan pada siswa SD karena anak umur 8 atau 9 tahun senang terhadap hal-hal yang konkret serta didukung oleh peningkatan rasa ingin tahu terhadap variabelvariabel tertentu

c. Kegiatan eksperimen tepat digunakan apabila memiliki media yang cukup, namun apabila tidak cukup dapat dilakukan melalui demonstrasi

d. Pola demonstrasi yang dapat dilakukan yaitu; teacher demonstration, teacherstudent demonstrastion, student group demonstration, individual demonstration, dan guest demonstration.

e. Muara keberhasilan belajar sains yaitu meningkatnya minat belajar melalui; kegiatan yang melibatkan siswa, adanya sentuhan psikologis dan pengertian, suasana adil dan demokratis.

\section{F. Daftar Pustaka}

Bodgan, R.C., \& Biklen, S.K. (1982). Qualitative research for education: An
Introduction Theory and Method. Toronto:Allyn and Bacon Inc.

Carin \& Sund. (1981). Teaching modern science. Columbus:Charles E. Merrill Publishing Company

Gie, The Liang. (1982). The interrelationship of science and technology (a systematic clarification for the development of science and technology Policy in Indonesia). Yogyakarta:Yayasan Studi IImu dan Teknologi

Joyce, Bruce \& Weill, Marsha. (1996). Models of teaching. USA:Allyn \& Bacon, a Simon \& Schuster Company 